Research Article

\title{
An Exploratory Research of Manufacturer-Retailer Collaboration in Shopper Marketing Strategy for Consumer Packaged Goods in Vietnam
}

\author{
Tram Thi Le Dinh, Bao Quoc Truong-Dinh \\ ${ }^{1,2}$ University of Economics-The University of Danang
}

\begin{abstract}
The purpose of this paper is to explore the collaboration between manufacturer and retailer in shopper marketing strategy for consumer packaged goods (CPG) in Vietnam. The research integrates relevant theories of collaboration in shopper marketing and conducts empirical research through in-depth interviews with managers of CPG manufacturers and retailers of the traditional and modern channel systems. The results show the significant difference about shopper marketing activities and the collaboration between two channels (traditional and modern). The traditional retail system has limited resources and differences in objectives and viewpoints, so it is not willing to cooperate in the implementation of marketing programs in stores. In contrast, modern retailers such as supermarkets and convenience stores show a high commitment to closely working with manufacturers to launch marketing activities in stores.
\end{abstract}

Keywords: Shopper marketing, In-store marketing, Manufacturers-retailers collaboration, Consumer packaged good, Traditional retailers, modern retailers.

\section{Introduction}

The manufacturer-retailer relationship has moved away from transactions towards a cooperative relationship with a longterm perspective (Morgan \& Hunt, 1994; Weitz and Japp, 1995). In the field of consumer packaged goods (CPG), the relationship between channel members is not always close and robust because of the nature of the commodity (Zondag et Brink, 2015). Most CPG manufacturers utilize a pull marketing strategy for objectives to build brand equity and gain end consumers. Downstream retailers, in turn, focused on shoppers with the objective to attract and retain customers. However, with changes of environment, insights about customers shopping behavior become crucial with the rise of shopper marketing practice. Shopper marketing is a recent concept, and it has been gaining importance and attention among managers and researchers (Silveira \& Marreiros, 2014). With the emergence of shopper marketing, "retailers" and "brand manufacturers" are collaborating in more strategic ways in order to understand and serve specific shoppers (Flint et al. 2014, Bogetic et al., 2016). Channel collaboration is discussed extensively (Kim et al., 2013), but the collaboration regarding marketing between manufacturers and retailers still requires more investigation (Flint et al., 2014; Silveira \& Marreiros, 2014).

Regarding the shopper marketing, retailers and CPG manufacturers need to closely cooperate to attract and convince customers across their shopping journey. The collaboration between CPG manufacturers and retailers to improve brand equity for CPG manufacturer and retail brands, fine-tune product assortment, plan in-store promotions, product pricing, and other critical elements of the CPG retail marketing mix that together create a positive shopping experience (Zondag \& Brink, 2015).
In Vietnam, the traditional system of the CPG industry under the form of traditional markets, grocery stores accounts for $50 \%$ of retail sales (Neilson Report, 2015). Therefore, the collaboration between channel members is considered a problem in the implementation of shopper marketing activities in stores. With the reality of this channel system, in order to enhance the cooperation among channel members in the implementation of marketing activities in stores, it is necessary to understand the actual situation as well as the views of the parties on cooperation in shopper marketing, from which proposing solutions to strengthen cooperation in the channel.

Our research uses the theoretical foundations of channel collaboration and shopper marketing in the aim of well understanding the reality of channel collaboration in shopper marketing for CPG in Vietnam. Specifically, the study is going to (1) synthesize the theoretical foundations of channel marketing and shopper marketing, (2) explore the reality of channel collaboration in shopper marketing through in-depth interviews with both manufacturers and retailers to assess the current situation, demands, views and challenges, and difficulties that hinder the collaboration in the implementation of shopper marketing.

The primary hypothesis is that shopper marketing planning and implementation play an important role in enhancing delivery channel partnerships in the CPG industry (Bogetic et al., 2016; Silveira \& Marreiros, 2014). The study also aims to verify the differences regarding collaboration within the modern channel system compared to the traditional channel system.

\section{Literature Review}

The determinant of manufacturer-retailer cooperation 


\section{Tram Thi Le Dinh et al / An Exploratory Research of Manufacturer-Retailer Collaboration in Shopper Marketing Strategy for Consumer Packaged Goods in Vietnam}

Factors influencing collaboration between manufacturers and distributors include structural factors and social and psychological factor (Cullen et al., 2000). The structural factors include mutual manufacturer-distributor dependence on resources and capabilities, social compatibility with congruence of goals and cultural compatibility. These factors create a favorable environment for cooperation. In addition, the social and psychological aspects focus on the interaction between partners such as mutual trust, information exchange, reciprocal commitment, developing interfirm knowledgesharing routines, contributes to the efficient day-to-day working of manufacturer-distributor cooperation (Song et al., 2008). Cooperation agreement will be attended with three conditions: (1) partners must have compatible goals; (2) resources and capabilities must complement each other, and (3) the risk that is run if the partner engages in opportunistic practices must be low, whilst environmental risk must be high (Lado et al.,1997). In particular, Jap (2001) used the buyersupplier dyad as the unit of analysis; he concluded that the conditions for cooperation are goal congruence, complementary resources, and capabilities, quality of the interpersonal relationship.

In general, enhancing cooperation require complementary resources and capabilities of the partners and goal congruence, trust and relational norms (Vazquez et al., 2005). Cooperation between manufacturer and distributors involves reciprocal commitment and joint investment in specific assets. This cooperation should help partners gain satisfaction from the economic, psychological or social benefits of the cooperation and competitive advantage, profits and strategic outcomes that help them to compete in the market more efficiently (Hammervoll, 2009).

Cooperation agreements in the distribution channel can be classified into two focuses, cooperation in a physical distribution such as the frequency and volume of transactions, information exchange and cooperation in marketing concerning marketing strategy execution (Vazquez et al. (2005). Besides, the tendency of cooperation in the implementation of shopper marketing recently gain the attention of many research (Zondag \&Brink, 2015).

\section{Manufacturer - retailer cooperation in the context of shopper marketing}

Shopper marketing is a way in which brand names, retailers and all other support partners work together to develop strategic marketing and distribution (Flint et al., 2014). The result of these efforts is the efficiency of communication throughout the whole process that leads to the customer's shopping behavior from outside activities to the display of the goods, thereby changing the buying experience.

Terms of in-store marketing or shopper marketing first emerged in 2004 in research of Coca-Cola Retailing Research Council of North America. In this study, we use the term shopper marketing for both levels: in-store marketing and shopper marketing.

Shopper marketing is all marketing activities that influence a shopper along and beyond the path-to-purchase (Shankar, 2014). "Shopper Marketing is the use of insights-driven marketing and merchandising initiatives to satisfy the needs of targeted shoppers, enhance the shopping experience, and improve business results and brand equity for retailers and manufacturers" (Retail Commission on Shopper Marketing, 2010).

The importance of the shopper marketing subject is multifold (Bogetic et al., 2016). Shopper marketing is a marketing effort that creates a better buying experience, thereby maintaining customer loyalty, contributing to improve the business results. Second, this is a new approach to collaboration in the marketing channel with a focus on shoppers, in other words, shopper marketing takes on the challenge of connecting channel members and driving them to the same view of active shopper marketing development.

Silveira et Marreiros (2014) proposed a classification of shopper marketing literature in broad and narrow works. The broad works are those that study shopper marketing as a whole and comprehensively, while the narrow ones are those that focus on one or few specific aspects included in the shopper marketing concept. The main broad works confirm the essential factor to effective shopper marketing is a collaboration (Retail commission on Shopper marketing, 2010). The retailer - supplier partnership on comprehensive customer care is the core of the shopper marketing concept (Silveira \& Marreiros, 2014). Channel relationship issues related to shopper marketing initiatives are always the top concern of executives and researchers (Dukes \& Liu, 2010).

According to Bogetic et al. (2016), effective and efficient shopper marketing is based on a balanced partnership between retailers and suppliers, and this partnership is supported by improvements in category management and adjustments in performance metrics. The core platform for increasing channel collaboration through shopper marketing is the development of a shopper marketing plan which should be followed from both manufacturers and distributors. (Retail Commission on Shopper Marketing, 2010). Developing the framework of this plan will provide the basis for collaboration whereby there is a compatibility between the target customer segment of distributors and manufacturers. By defining the priority of customer segments, distributors can coordinate with manufacturers to identify common opportunities to reach potential customers that satisfies both parties' goals.

Retail Commission on Shopper Marketing (2010) proposed model consist three levels of development that guide the Shopper Marketing Plan from strategic concepts to tactical activity to orient the cooperative activities; enable the parties to match the objectives, expectations; assign the roles; and clearly define all the necessary elements for the operation. The model proposed by the American Retail Association consists of three levels of cooperation:

1. Development of a Strategic Framework that ensures the Shopper Marketing Plan is linked to the retailer's go-to-market strategies and is aligned with the target shoppers and consumers of the retailer and partnering 


\section{Tram Thi Le Dinh et al / An Exploratory Research of Manufacturer-Retailer Collaboration in Shopper Marketing Strategy for Consumer Packaged Goods in Vietnam}

manufacturer.

2. Development of a Platform that describes the Shopper Marketing Plan's key communication strategies.

3. Development of Programs that deliver the Platform's message to target shoppers.

Shankar (2011) proposed five fields of shopper marketing and analyzed from the point of view of retailer, supplier, and shopper. These fields are offer view, availability, sales promotion and displays additional positions.

For monitoring the performance of joint work on shopper marketing, Bogetić et al. (2016) proposed that shopper marketing require much deeper cooperation between suppliers and retailers than it was the case in traditional marketing. It is necessary that common goals should be set, and then measures for achieving these goals established.

\section{Research Method}

\section{Research setting}

This research was conducted in Vietnam, a developing country with a unique business environment that exists both modern and traditional retail channels at the same time in the consumer goods sector. In which, the traditional channel is still playing an important role; according to the Neilsen (2015) report, in Vietnam, this kind of channel accounts for nearly $50 \%$ of retail sales, in Ho Chi Minh City this figure is $70 \%$. With the cultural characteristics of Vietnam, Vietnamese consumers are used to shopping with markets and eateries, so the traditional retail channel still occupies a large proportion. With a market of up to 1.3 million traditional stores and more than 2,000 modern trade outlets such as supermarkets and convenience stores, manufacturers of CPG make their best efforts to approach customers via this retail channel. The fact is that there is a great deal of difference in the practice and management of traditional versus modern retailers, which has implications for channel collaboration and shopper marketing. It is, therefore, necessary to distinguish between traditional and modern channels when researching shopper marketing as well as identify the viewpoints of manufacturers and retailers about the channel collaboration in shopper marketing.

\section{Data collection}

The direct interview is the most appropriate qualitative research tool for exploratory research. Qualitative interviews are considered suitable for developing knowledge, understanding, and learning because they use an exploratory approach to find the phenomena (Olson, 2011).

In this study, the primary data were obtained from semistructured questionnaire through in-depth interviews conducted to how retailer and manufacturer managers expressed and reflected their thinking, perceptions, and thoughts about the distribution channel cooperation in shopper marketing.

The sampling procedure adopted the conventional method, whereby the sample objects are selected according to their permission. CPG is characterized by wide distribution through traditional and modern retail channels, so interviewees include managers of modern retail systems and owners of traditional retail stores. In particular, modern retail managers are welltrained and have excellent management skills as well as indepth knowledge of the industry, market and customer behavior, while traditional retailers are often unskilled, mainly based on personal experience and cannot operate a store systematically.

In this study, interview with $10 \mathrm{CPG}$ manufacturers, ten new trade and ten traditional retailers were conducted. The interview was conducted between May 5 and June 30, 2018, at respondents' office. The interview took place an average of one hour. Specifically, ten distribution managers of CPG manufacturers had seven male and three female interviewees, ten modern shop managers had six male and four female, while ten traditional retailers had one male and up to nine female interviewees. It can be seen that most of the grocery stores, the common form of the traditional retail channel, are household-based business activities undertaken by women.

\section{Interview process}

The interview process was carried out as recommended by (Olson, 2011) for the qualitative interview. Preparation for the interviews involved several procedures and decisions.

Step 1- Before the interview: the researchers directly contacted manufacturers representatives and arranged the time for the meeting.

Step 2 - Introduction to interview: the researchers informed about the purpose of the study and asked for recording all the discussion before the interviewing process begin.

Step 3- During the interviews: researchers applied active, interpretive, and process listening, All the interviewing was recorded, all communication materials were composed of transcriptions of oral communication, and some notes were taken regarding paralinguistic communication captured during recording.

The duration of the conversations, ranging from 45 to 60 minutes, depending on the responses from the participants, was found sufficient to allow all relevant information to emerge and achieve data saturation. Interviews were in Vietnamese, and the main questions were showed in table 1.

The sample was determined by interviewing $10 \mathrm{CPG}$ manufacturers and asked them to introduce two channel members, a traditional retailer and a modern retailer whose business is implementing shopper marketing. The interview focused on the manufacturer-retailer relationship in implementing shopper marketing activities. The topics and details of the interview were used for both representatives of manufacturers and retailers. The manufacturers would also mention about the partnership with the two traditional and modern retailers they introduced. 
Tram Thi Le Dinh et al / An Exploratory Research of Manufacturer-Retailer Collaboration in Shopper Marketing Strategy for Consumer Packaged Goods in Vietnam

Table 1: Themes, Questions, and Focus used in the interviews

\begin{tabular}{|c|c|c|}
\hline Theme & Questions & Focus \\
\hline Shopper marketing activities & $\begin{array}{l}\text { The shopper marketing activities have been } \\
\text { implemented } \\
\text { 1. What kind of shopper marketing } \\
\text { activities has the business been } \\
\text { implementing? }\end{array}$ & Shopper marketing activities \\
\hline $\begin{array}{l}\text { Channel collaboration in shopper } \\
\text { marketing }\end{array}$ & $\begin{array}{l}\text { What collaboration activities with channel } \\
\text { partners? } \\
\text { 1. Does the business have channel } \\
\text { partners? } \\
\text { 2. What areas of collaboration? } \\
\text { 3. Are there any collaborations in planning } \\
\text { and implementing shopper marketing } \\
\text { programs? } \\
\text { 4. What factors affecting the collaboration } \\
\text { with channel partners? }\end{array}$ & $\begin{array}{l}\text { Collaboration between parties in shopper } \\
\text { marketing } \\
\text { Factors affecting the collaboration }\end{array}$ \\
\hline $\begin{array}{l}\text { Viewpoints on the importance of } \\
\text { channel collaboration in shopper } \\
\text { marketing }\end{array}$ & $\begin{array}{l}\text { How important is shopper marketing } \\
\text { activities to the sales of the business? }\end{array}$ & $\begin{array}{l}\text { Viewpoints of the parties on the } \\
\text { importance of channel collaboration in } \\
\text { shopper marketing. }\end{array}$ \\
\hline $\begin{array}{l}\text { Constraints of } r r \text { channel } \\
\text { collaboration in shopper marketing }\end{array}$ & $\begin{array}{l}\text { What are the challenges and difficulties in } \\
\text { implementing channel collaboration? } \\
\text { 1. In the process of channel collaboration, } \\
\text { what difficulties does the business } \\
\text { encounter? } \\
\text { 2. What are the contradictions among } \\
\text { channel partners? }\end{array}$ & $\begin{array}{l}\text { Difficulties and challenges parties have to } \\
\text { face during the collaboration }\end{array}$ \\
\hline
\end{tabular}

\section{Findings and Discussion}

In this study, the results of in-depth interviews confirm the initial comments of the differences between traditional and modern channels in channel collaboration and shopper marketing. Traditional retailers have a lower degree of cooperation than modern retailers in implementing shopper marketing. A detailed breakdown is provided through the analysis of survey data and then presented in Table 2 for the traditional channel including traditional retailers and CPG manufacturers, and Table 3 for modern channels.

Table 2: Summary keywords related to channel collaboration and shopper marketing in the traditional channel

\begin{tabular}{|c|c|c|}
\hline Themes & $\begin{array}{l}\text { Keywords for traditional } \\
\text { retailers }\end{array}$ & Keywords for CPG manufacturer \\
\hline \multirow[t]{4}{*}{ Shopper marketing activities } & Category management $(7 / 10)$ & Category management (10/10) \\
\hline & Sale promotions $(4 / 10)$ & Sale promotion program $(8 / 10)$ \\
\hline & Sale assistants $(3 / 10)$ & Sale assistants $(7 / 10)$ \\
\hline & Merchandising $(5 / 10)$ & Merchandising $(7 / 10)$ \\
\hline \multirow{4}{*}{$\begin{array}{l}\text { Channel collaboration in shopper } \\
\text { marketing }\end{array}$} & Order fulfillment $(8 / 10)$ & Physical distribution $(8 / 10)$ \\
\hline & Disadvantages $(8 / 10)$ & Order fulfillment (10/10) \\
\hline & & Disadvantages (7/10) \\
\hline & & Uncooperativeness $(6 / 10)$ \\
\hline \multirow[t]{4}{*}{ Viewpoints on the channel collaboration } & Not too important $(6 / 10)$ & Very important $(8 / 10)$ \\
\hline & Very important $(4 / 10)$ & Limited when working with traditional retailers \\
\hline & Complicated (7/10) & $(7 / 10)$ \\
\hline & Less effective (6/10) & \\
\hline \multirow[t]{3}{*}{ Constraints for channel collaboration } & Not enough resources $(8 / 10)$ & Retailers are not ready $(8 / 10)$ \\
\hline & & $\begin{array}{l}\text { Retailers do not share the same points of view } \\
(10 / 10)\end{array}$ \\
\hline & & Retailers do not have adequate resources $(9 / 10)$ \\
\hline
\end{tabular}


Tram Thi Le Dinh et al / An Exploratory Research of Manufacturer-Retailer Collaboration in Shopper Marketing Strategy for Consumer Packaged Goods in Vietnam

Be difficult in communication $(8 / 10)$

Table 3: Summary keywords related to channel collaboration and shopper marketing in modern channel

\begin{tabular}{|c|c|c|}
\hline Themes & Keywords for modern retailers & Keywords for CPG manufacturers \\
\hline Shopper marketing activities & $\begin{array}{l}\text { Category management }(10 / 10) \\
\text { Sale promotion program }(10 / 10) \\
\text { Merchandising }(10 / 10) \\
\text { Sale assistants }(8 / 10)\end{array}$ & $\begin{array}{l}\text { Category management }(10 / 10) \\
\text { Sale promotion program }(10 / 10) \\
\text { Merchandising }(10 / 10) \\
\text { Sale assistants }(8 / 10)\end{array}$ \\
\hline $\begin{array}{l}\text { Channel collaboration in shopper } \\
\text { marketing }\end{array}$ & $\begin{array}{l}\text { Customer data and insight }(8 / 10) \\
\text { Planning }(7 / 10) \\
\text { Implementation of shopper program } \\
(10 / 10) \\
\text { Physical distribution }(10 / 10) \\
\text { Regularity }(8 / 10) \\
\text { Closeness }(6 / 10)\end{array}$ & $\begin{array}{l}\text { Sharing customer data and insight }(9 / 10) \\
\text { Planning }(7 / 10) \\
\text { Order fulfillment }(10 / 10) \\
\text { Sales data }(10 / 10) \\
\text { Regularity }(10 / 10) \\
\text { Effectiveness }(9 / 10)\end{array}$ \\
\hline $\begin{array}{llll}\text { Viewpoints on the channel } \\
\text { collaboration }\end{array}$ & $\begin{array}{l}\text { Very important }(7 / 10) \\
\text { Effective shopper marketing program } \\
(8 / 10) \\
\text { Ready to collaborate }(8 / 10)\end{array}$ & $\begin{array}{l}\text { Crucial }(10 / 10) \\
\text { Strategic partner }(8 / 10) \\
\text { Shopper insight }(8 / 10) \\
\text { Mobilize all resources to collaborate }(9 / 10) \\
\text { Help increase the competitiveness of the } \\
\text { brand }(6 / 10)\end{array}$ \\
\hline Constraints for channel collaboration & $\begin{array}{l}\text { Different in purpose }(6 / 10) \\
\text { Conflicts of interest }(8 / 10) \\
\text { Limited in communication }(6 / 10) \\
\text { Require a lot of investment }(5 / 10)\end{array}$ & $\begin{array}{l}\text { Communication }(7 / 10) \\
\text { Sometimes retailers require a lot of benefits } \\
(7 / 10) \\
\text { Conflicts about sales targets and branding } \\
(7 / 10)\end{array}$ \\
\hline
\end{tabular}

Shopper marketing is systematically implemented in the modern channels and fragmentary in traditional channels.

Modern manufacturers and retailers discuss shopper marketing activities such as catalog management, goods display, shopper activities like PG or publications on promotion.

An area manager of Brand B (43 years old) said, "Shopper marketing activities with modern retailers such as supermarkets and convenience stores are very effective. With customer database that partners have shared, we can easily track demand fluctuations and capture customer insight in order to plan as well as execute shopper programs".

Meanwhile, at the traditional retail stores, the shopper marketing model merely manages the list of items manually because most traditional retailers prefer to record manually and do not utilize information technology. Grocery stores are usually undertaken by their owners and are less likely to be involved in shopper marketing, but primarily related to categories management.

Typically, a manager of Brand D (35 years old) assessed "shopper marketing activities with traditional retailers are very poor. They only manage the catalog and some display activities. Due to space constraints, it is not possible to develop display plans such as targeted; also, promotion programs do not work effectively in grocery stores".

Modern manufacturers - retailer channel collaboration, including supermarkets and convenience stores, works quite effectively when implementing shopper marketing activities.

Channel collaboration takes place frequently and effectively between modern manufacturers and retailers; in particular, most of the respondents mentioned important collaborative segments in the physical distribution such as sharing information of sales, orders, categories management. Both sides also specified some collaborative segments related to shopper marketing such as sharing customer information and customer insight, the regular and close collaboration in planning and implementing shopper marketing activities.

Supermarket is an important distribution partner in the CPG sector and accomplishing shopper marketing activities thanks to the close cooperation from partners. At the same time, representatives of modern retailers also shared their interest in shopper marketing activities as well as collaboration with manufacturers. A representative of the $\mathrm{CPG}$ sector of $\mathrm{E}$ supermarket assumed, "Shopper activities of the manufacturers have well supported in attracting customers. Programs are built along with a wide communication have gained a big number of shoppers into the supermarket, motivated them to place orders, contributing to the increase in sales". In line with this view, a distribution manager of manufacturer $\mathrm{N}$ said, "A collaboration, for example, a customer database shared by supermarkets, plays an important role in developing effective marketing programs. Similarly, the serious implementation of shopper programs at the supermarkets creates a high efficiency for the programs of the 
brand".

As for the viewpoint of collaboration in shopper marketing, modern retailers and manufacturers have a fairly consistent perspective on its importance, in particular, they are interested in investing in shopper marketing to boost sales and be ready to cooperate for higher efficiencies. In contrast, traditional retailers underestimate the effectiveness of shopper marketing activities. They also ignore the cooperative relationship with the manufacturers and thus put limited resources into this relationship.

The primary barriers to collaboration with traditional retailers about differences in objectives and resource constraints

Traditional retailers cooperate at a basic level with the main physical distribution activities, such as sharing sales data, coordinating with the manufacturers in the catalog management and ordering. This fact stems from that traditional retailers are not well aware of the need for channel collaboration in the implementation of shopper marketing. Besides, there are many barriers to channel collaboration, which has limited the effectiveness of shopper marketing programs. The director of Brand $\mathrm{G}$ said that "traditional retailers in the form of grocery stores are very limited in resources, and because this type of retailers makes up a large quantity but with a small scale, the investment on all stores is costly and inefficient." A manager of Brand T said, "Grocery store owners often retain special offers, so promotion programs are mostly ineffective with this channel, in addition, if we do not work actively to reload goods, storekeepers will also let goods out of stock, so we have to work harder to ensure goods are always available for them to sell. Generally, without collaboration with such these retailers, we have to make much more efforts." Meanwhile, the grocery store owner Q said, "Shopper operations are not always important to my sales. Most customers are regular and return customers, who can determine what they are going to buy. In cases that customers need advice, I am the one who often makes a comment and recommendations."

Upon summing up the results of interviews with manufacturers and grocery stores, there are some significant barriers to collaboration and shopper marketing. First, traditional retailers are primarily small-scale grocery stores and household businesses, so their professional skills are limited, their business operation is fragmented and spontaneous. Second, the resources of traditional retailers are not well-suited with limited spaces that do not allow for the optimal goods display as planned. They also record the data manually rather than managing it by computer systems, which makes the synthesis and sharing of information slow and inaccurate. Third, traditional retailers have different perspectives and objectives with the manufacturers' on shopper marketing and collaboration. Specifically, retailers are confident that they are well aware of customers' demand and have a good relationship with the customers. They currently satisfied with their sales effect, without the needs for additional support from the manufacturers as well as the cooperation in shopper marketing activities. A shopkeeper of the grocery store $\mathrm{K}$ said, "My shop is working very efficiently. Many kinds of goods cost cheaper than supermarkets, so special offers or display activities are not necessary. I have an excellent customer service mindset, most of the customers are familiar with the shop, and they often ask for my advice when choosing a good."

The unwillingness of traditional retailers to cooperate in shopper marketing comes from the perception of the power of the traditional retail form - a form of distribution that is ingrained in the Vietnamese's habit of living which appreciates the convenience with respect to location near their homes, and the confidence of traditional retailers in their role in influencing customers' purchase decision.

\section{Conclusions}

The study has contributed to the research on channel collaboration and shopper marketing in the CPG industry. Especially, investigated in the Vietnamese context, the study shows the differences between traditional and modern channels in the implementation of shopper marketing and channel collaboration. The survey simultaneously explores the views of both parties, manufacturers, and retailers, about shopper marketing and channel collaboration. The results demonstrate the unity of views of the two - manufacturers and retailers - in both traditional and modern channels - on the reality of shopper marketing and channel collaboration. It can be said that most of the CPG retailers have merely implemented shopper marketing, but less likely to develop marketing programs that combine out the store and in-store oriented towards shoppers. With the modern CPG retailers, shopper marketing and co-operation with manufacturers are made frequently and effectively, while with traditional retailers, this level of cooperation is relatively restricted. Recognizing the constraints that impede collaborative efforts of shopper marketing would contribute to propose management implications for both manufacturers and retailers in the CPG sector.

\section{Research and Management Implications}

This study contributes some new points to research in the field of channel collaboration and shopper marketing. First, the study adopted a bilateral approach to explore the viewpoints of both manufacturers and retailers on shopper marketing activities and channel collaboration. Second, because the research problem is relatively new and has not been studied in Vietnam, the in-depth interview method allowed gathering comments from the channel members. Third, with the characteristics of Vietnam's distribution channel, the survey on traditional and modern retailers highlighted differences in views, perceptions, and behaviors of these two channel members.

Regarding management practices in the CPG sector, the study shows that manufacturers are very interested in shopper marketing and cooperative efforts with retailers. However, there are several barriers to their cooperation in shopper 


\section{Tram Thi Le Dinh et al / An Exploratory Research of Manufacturer-Retailer Collaboration in Shopper Marketing Strategy for Consumer Packaged Goods in Vietnam}

marketing, especially with traditional retailers. To enhance channel collaboration and improve the effectiveness of shopper marketing activities oriented towards customers, some of the proposals are provided from practical research.

First, with 1.3 million traditional stores in the form of grocery stores, CPG manufacturers find it difficult to carry out marketing activities at these outlets due to the lack of professionalism and cooperation in implementation. It is, therefore, necessary to increase investment so that traditional retailers have the resources to meet the requirements of shopper marketing programs and work in a way that is comparable to that of manufacturers. The investment can come from both sides, from traditional retailers themselves, such as self-equipping computer systems, applying information technology in management, raising management awareness and capacity. Manufacturers can offer support such as training, guiding to collect and process customer data, consulting in store design and goods display and so on; gradually helping traditional retailers catch up with the pace of development, gaining the same level of useful service.

Second, raise the awareness of traditional retailers about the importance of shopper marketing activities to change their attitudes and thereby change cooperative behavior in implementing promotion programs and other shopper marketing activities.

Third, in the traditional retail channel, limit the stocking rate, require more close coordination between retailers and manufacturers in forecasting and planning supply activities. Finally, since the traditional retailers have a close relationship and deep understanding of the customer, manufacturers should work with them to promote the brand.

As for modern channels like supermarkets and convenience stores, there are almost no significant barriers to cooperation and shopper marketing. The most significant consideration for this system is the need to develop a logical process or a framework for cooperation between manufacturers and retailers in the planning and implementation of shopper marketing programs. Encouraging modern retailers to participate in the planning process would integrate their goals with the manufacturers' goal, thereby reducing conflicts and giving them greater incentives and commitment while implementing shopper marketing programs.

\section{Limitations and Future Research}

This study also has some limitations. First, qualitative research through in-depth interviews has some limitations on the nature of the tool. The data collection, as well as the exploitation and analysis of data considerably, depending on the knowledge and skills of the researcher. The next limitation involves interviewing the traditional retailers who have difficulty communicating; most traditional retailers do not have a clear business strategy and plan, so the application of research concepts is not really effective; besides, the majority of respondents are shopkeepers who are occupied with selling goods all the time, so the interview was interrupted anywhen customers entered.
This study explores the reality of channel collaboration in shopper marketing from the viewpoints of both manufacturers and retailers in two traditional and modern channel systems, which may be premise for some future research direction, such as the model study of factors affecting channel collaboration in shopper marketing and the development of collaborative framework for channel members to enhance effectiveness of shopper marketing activities.

\section{Funding}

This paper is financed by the Ministry of Education and Training of Vietnam through Project No. B2016-ĐNA-05 in 2016. Leader researcher is Dr. Dinh Thi Le Tram.

\section{References}

1. Bogetić, Z., Kaličanin, Đ., \& Stojković, D. (2016). Shopper marketing: A new partnership perspective in marketing channels. Ekonomski Horizonti, 18(1), 53-69.

2. Bogetić, Z., Stojković, D., \& Milošević, S. (2016). Shopper marketing strategy in food retailing. Economics of Agriculture, 63(1), 189-204.

3. Cullen, J. B., Johnson, J. L., \& Sakano, T. (2000). Success through commitment and trust: The soft side of strategic alliance management. Journal of World Business, 35(3), 223-240.

4. Dukes, A., \& Liu, Y. (2010). In-store media and distribution channel coordination. Marketing Science, 29(1), 94-107.

5. Flint, D. J., Lusch, R. F., \& Vargo, S. L. (2014). The supply chain management of shopper marketing as viewed through a service ecosystem lens. International Journal of Physical Distribution \& Logistics Management, 44(1/2), 23-38.

6. GMA Sales Committee (2010), "Shopper marketing 4.0: building scalable playbooks that drive results", GMA and Booz \& Co. Industry Report, Grocery Manufacturers Association Sales Committee, Washington, DC

7. Hammervoll, T. (2009). Channel cooperation: a reflective scale. The International Journal of Logistics Management, 20(3), 301-321.

8. Jap, S. D. (2001). Perspectives on joint competitive advantages in buyer-supplier relationships. International Journal of Research in Marketing, 18(1-2), 19-35.

9. Lado, A. A., Boyd, N. G., \& Hanlon, S. C. (1997). Competition, cooperation, and the search for economic rents: A syncretic model. Academy of Management Review, 22(1), 110-141.

10. Morgan, R. M., \& Hunt, S. D. (1994). The commitmenttrust theory of relationship marketing, 58(3), Journal of Marketing, 20-38.

11. Neilsen Report. (2015). Traditional Trade Regional report in 2015. Available at: https://www.nielsen.com/vn/vi/ insights/2015/traditional-trade-regional-2015.html (accessed in June 29, 2018)

12. Olson, K. (2011). Essentials of Qualitative Interviewing. New York: Routledge. 
13. Retail Commission on Shopper Marketing (2010), Shopper Marketing Best Practices: A Collaborative Model for Retailers and Manufacturers, Industry Report, In-store Marketing Institute, Chicago, IL Available at: https://retailhouse.files.wordpress.com/2016/06/shoppermarketing-best-practices-report-4-2010.pdf (accessed in June 29, 2018)

14. Shankar, V. (2011). Shopper Marketing. Cambridge, Massachusetts: Marketing Science Institute.

15. Shankar, V. (2014). Shopper marketing 2.0: opportunities and challenges. In Shopper Marketing and the Role of InStore Marketing (pp. 189-208). Emerald Group Publishing Limited.

16. Silveira, P. D., \& Marreiros, C. (2014). Shopper marketing: a literature review, 4(1), International Review of Management and Marketing, 90-97.

17. Song, M., Di Benedetto, C. A., \& Zhao, Y. (2008). The antecedents and consequences of manufacturerdistributor cooperation: an empirical test in the US and Japan. Journal of the Academy of Marketing Science, 36(2), 215-233.

18. Vazquez, R., Iglesias, V., \& Álvarez-gonzález, L. I. (2005). Distribution channel relationships: The conditions and strategic outcomes of cooperation between manufacturer and distributor. The International Review of Retail, Distribution and Consumer Research, 15(2), 125150.

19. Weitz, B. A., \& Jap, S. D. (1995). Relationship marketing and distribution channels. Journal of the Academy of Marketing Science, 23(4), 305-320.

20. Zondag, M. M., \& Brink, K. E. (2015). Developing a new theory of frontline manufacturer-retailer relationships for consumer packaged goods. Journal of Business-toBusiness Marketing, 22(4), 313-331. 